\title{
Pig farming systems and cysticercosis in Northern Uganda
}

\author{
Joseph Morison Kungu' ${ }^{1}$ Charles Masembe ${ }^{2}$ \\ Michael Apamaku ${ }^{3}$ Joyce Akol ${ }^{4}$ \\ Winfred Christine Amia ${ }^{4}$ Michel Dione ${ }^{4 *}$
}

\section{Keywords}

Swine, livestock management, Taenia spp., cysticercosis, seroprevalence, risk factors, Uganda

\footnotetext{
Submitted: 14 July 2017

Accepted: 5 September 2019

Published: 30 September 2019

DOI: $10.19182 /$ remvt.31254
}

\begin{abstract}
Summary
Rudimentary non-market-oriented pig rearing systems have been implicated in the persistence of Taenia solium cysticercosis, an endemic disease of high public health concern in Uganda. We investigated the seroprevalence and key predisposing factors of the disease in Moyo and Lira, two pig-producing districts in Northern Uganda. Cross-sectional serosurveys were conducted in 428 pig farms (Moyo, 262; Lira, 166). Farmers kept on average two adult pigs per herd. Tethering was a common practice in rural areas; free-ranging less so. Confinement of pigs in pens was characteristic of periurban farming systems. Pigs were mainly fed crop residues and forages in the rainy season, and swill and crop residues in the dry season. The majority of farmers of the survey were women $(55 \%)$ above 45 years old, and $51 \%$ of farmers had attained primary school education. A total of 723 pig serum samples were collected, 403 in Moyo, and 320 in Lira. They were analyzed for Taenia spp. antigens using B158C11A10/B60H8A4 Antigen-ELISA. The overall animal seroprevalence of Taenia spp. serum antigen was $10.4 \%$ (95\% confidence interval [Cl]: 4.9-17.6), with $13.2 \%(95 \% \mathrm{Cl}: 7.1-$ 21.2) the highest in Moyo vs $6.9 \%(95 \% \mathrm{Cl}: 2.9-13.9)$ in Lira. The herd-level seroprevalence was estimated at $13.7 \%$ (95\% Cl: 9.8-18.5) in Moyo and $11.4 \%$ (95\% Cl: 7.0-17.2) in Lira. Out of 12 explanatory variables assessed for association with the observed seroprevalence, only the district of origin was significant $(p=0.01)$. Pigs originating from Lira were a protective factor against Taenia spp. cysticercosis (odds ratio: 0.54). These findings highlight the urgent need for an awareness campaign with prevention and control measures to minimize the risk of transmission to pork consumers in these districts.
\end{abstract}

- How to quote this article: Kungu J.M., Masembe C., Apamaku M., Akol J., Amia W.C., Dione M., 2019. Pig farming systems and cysticercosis in Northern Uganda. Rev. Elev. Med. Vet. Pays Trop., 72 (3): 115-121, doi: 10.19182/remvt.31254

\section{INTRODUCTION}

In recent years the rural poor, and middle income urban communities in Uganda have come to appreciate pig production systems as an important source of income and financial security (Ouma, et al., 2014). Pork production has been promoted as a fairly inexpensive option to address protein deficiency, given the limited consumption of animal source foods in Uganda (FAOSTAT, 2014). In Central and Eastern

\footnotetext{
1. College of Veterinary Medicine, Animal Resources and Biosecurity, Makerere University, Kampala, Uganda.

2. College of Natural Sciences, Department of Zoology, Entomology and Fisheries Sciences, Makerere University, Kampala, Uganda.

3. National Agricultural Research Organization, Abi Zonal Agricultural Research and Development Institute, Arua, Uganda.

4. International Livestock Research Institute, C/O Bioversity International, PO Box 24384, Kampala, Uganda.

* Corresponding author

Email: m.dione@cgiar.org
}

Uganda, free-ranging, tethering and housing management systems are common farming systems for rearing pigs. These management systems tend to be used interchangeably depending on seasonal patterns (Dione et al., 2014; Muhanguzi et al., 2012). The increase in pig production in response to the increasing urban pork consumption in Uganda represents a market opportunity for rural producers if they can guarantee the production of disease-free pork. However, good biosecurity practices are not uniformly applied along the pig value chain (Dione et al., 2017). The authors of these studies observed that practices where biosecurity and hygiene are poor have a high potential for disease transmission, and this risk is greater when the pathogen is zoonotic In free-ranging, tethering pig-rearing systems if hygiene and sanitation are poor, they are key drivers of transmission of pig diseases such as Taenia solium cysticercosis, a condition of high public health concern. In pig-keeping systems in Uganda, some socio-cultural practices may undermine good hygiene and sanitation; scarcity of feed and water in the dry season may encourage free-range management, compromising the implementation of strategies to control and prevent cysticercosis (Adenuga et al., 2018; Krecek et al., 2012; Kungu et al., 2017b). 
The stage of infection with T. solium determines the outcome and/or prognosis of infection in humans. Human infection by consumption of encysted larval stages of $T$. solium in undercooked pork completes the life cycle, with development of pork tapeworms (taeniasis), which has implications on growth and development in children. More deleterious effects to human health result when humans become intermediate hosts. Under these circumstances the larval stages of the parasite become encysted in the brain and muscles of humans. Development of larval cysts in the human brain or neurocysticercosis may result in epileptic seizures, even death. Both humans and pigs acquire cysticercosis by ingesting food or fluids contaminated with T. solium eggs shed in the feces of humans with taeniasis (Carabin et al., 2009; Mwape et al., 2015).

Previous prevalence studies have reported the occurrence of the condition in various developing countries in Asia, Latin America and Africa. In Uganda, available studies indicate an emerging T. solium cysticercosis problem (Adenuga et al., 2018; Praet et al., 2009; Rodriguez-Hidalgo et al., 2006; Sciutto et al., 2003; Sreedevi et al., 2012). Recent studies in Uganda have reported a high occurrence of the condition in pigs, in both rural and urban settings in Central and Eastern Uganda, and discussed potential risk factors (Kungu et al., 2017a,b). An investigation of this condition in the remote rural settings of Northern Uganda where pig production is steadily increasing will provide more insight on the situation in larger geographical parts of the country. Although there have been efforts to undertake studies to document cysticercosis in Uganda, limited research has been done to assess the magnitude of infection in pig production systems in the Northern area. This study thus aimed to describe the pig production systems and determine the prevalence and risk factors for cysticercosis in the Northern districts of Lira and Moyo.

\section{MATERIALS AND METHODS}

\section{Study area}

Cross-sectional surveys were conducted in July 2015 in Lira and Moyo districts (Figure 1). Lira has a human population of 410,516 and Moyo of 137,439 . The target subcounties surveyed constituted $47 \%$ and $39 \%$ of this population, respectively. Together these two districts have $11 \%$ of the total pig population in Northern Uganda with 28,631 pigs in Lira and 9,034 pigs in Moyo (UBOS and MAAIF, 2009).

\section{Site selection}

In Moyo and Lira, the district veterinary officers (DVOs) and subcounty veterinary personnel assisted to identify the subcounties with the highest pig population densities, and these subcounties were included in the current surveys. African swine fever (ASF) disease outbreak reports were used as an additional indicator for high pig population density. For data validation, the DVOs and para-veterinarians operating in the areas were consulted about their perceptions on pig populations in the target subcounties. Two subcounties in Moyo (Moyo, Metu) and five in Lira (Ojwina, Barr, Lira, Adyel and Adekokwok) were selected for the study. Based on the pig value chain domain classification that was previously used (Ouma et al., 2015), Moyo subcounties were all classified in the rural production domain. In Lira District, Adyel, Ojwina and Lira divisions were classified as periurban domains, whereas Barr and Adekokwok were classified as rural domains.

\section{Sample size calculation}

The pig population sample size was calculated considering an infinite population using the formula $\mathrm{n}=\left[\mathrm{Z}^{2} \mathrm{P}(1-\mathrm{P})\right] / \mathrm{d}^{2}$ (Thrusfield, 2007), and an estimated cysticercosis seroprevalence of $12.3 \%$, reported in Central and Eastern Uganda (Kungu et al., 2017a). The minimum sample size to detect a seroprevalence of cysticercosis with an
$80 \%-95 \%$ confidence interval was 166 pigs. We adjusted the sample size for intra-cluster correlation using a coefficient of 0.2. As a result, the adjusted sample size was estimated at 200 pigs per district. However, we sampled 320 pigs in Lira and 403 pigs in Moyo. Households enrolled in the survey were randomly selected from a list of farmers generated for each subcounty. In each household, up to three pigs were enrolled under random selection with the exclusion of pigs less than three months old, pregnant sows, and weak piglets.

\section{Ethical considerations}

Ethical approval was granted by the Research and Ethics Committee of the College of Veterinary Medicine, Animal Resources and Biosciences of Makerere University (Ref. No. SBLS/REC/15/128) and by the Ugandan National Council for Science and Technology (Ref. No. A508). All farmers signed a consent form to participate in the study and to allow their pigs to be sampled.

\section{Collection of household information and pig serum}

A pig biological data form and a household questionnaire were used to collect information on the individual pigs (age, sex and breed), farmers' demographic information (gender, age, nature of pig business, level of formal education, main source of income, etc.) and pig farming characteristics. For blood collection, pigs were restrained using a pig snare and bled from the anterior vena cava into $10-\mathrm{ml}$ plain vacutainers using 20 -gauge needles. Blood samples were transported in cold boxes to the district laboratories and kept overnight at room temperature to facilitate coagulation. Serum was harvested from the whole blood by pipetting into 2-ml cryovials and stored at $-20^{\circ} \mathrm{C}$ pending serological analysis.

\section{Key informant interviews}

Key informant interviews were carried out with DVOs and district production officers of respective districts in order to gain more information on pig production constraints. Such information was considered to support findings.

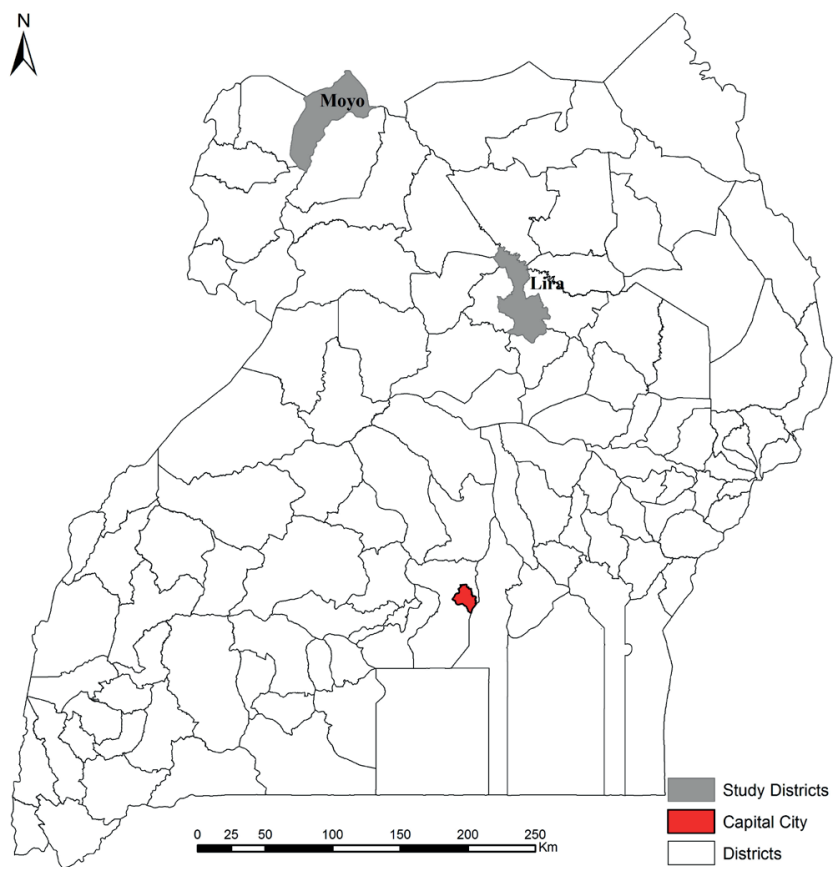

Figure 1: Map of Uganda showing the two districts of the study. 


\section{Serological analysis}

Serological analysis for Taenia spp. cysticercosis was carried out at the Molecular Biology Laboratory of the College of Natural Sciences, Department of Zoology, Entomology and Fisheries Sciences in Makerere University. Analyses were performed using B158C11A10/ B60H8A4 Antigen-ELISA (apDia In Vitro Diagnostic Kit, Belgium) following the manufacturer's instructions. The optical density (OD) of the samples was measured by reading the test plate at $450-\mathrm{nm}$ wavelength (Multiscan Ex, ThermoScientific). For the interpretation of results, the cut-off of the antigen index (Ag Index) for porcine specimens was calculated. The mean OD of the negative control was used to calculate the cut-off by multiplying its value by 3.5 . The $\mathrm{Ag}$ Index of each sample was calculated by dividing the OD value of the sample by the cut-off value. A positive reaction corresponded to an $\mathrm{Ag}$ Index greater than or equal to 1.3. A negative reaction corresponded to an $\mathrm{Ag}$ Index less than or equal to 0.8. When the $\mathrm{Ag}$ Index was between 0.8 and 1.3 , it was considered as a gray zone and samples were retested. They were considered as doubtful if the results remained the same and were excluded from the analysis. Positive and negative controls were provided by the manufacturer.

\section{Statistical analysis}

Individual pig biological data was entered in SPSS 16 for analysis. Samples that did not have biological information associated to them were removed from the analysis $(n=18)$. Descriptive statistics were used to analyze data on farmers' demographic characteristics as well as pig keeping and feeding systems. A logistic regression was conducted to determine associations between cysticercosis seroprevalence and potential risk factors. At first, a univariable analysis using a logistic regression was performed. Factors with $p \leq 0.2$ were expected to be included in a model for multivariable logistic stepwise regression analysis. Since the seroprevalence of cysticercosis was significantly different in the two districts, the logistic regression analysis of the explanatory variables was also independently done. Multivariable analysis was not conducted in any case because none of the variables were significant at univariable analysis.

\section{RESULTS}

\section{Farmers' demographic characteristics}

A total of 428 pig-keeping households were visited. Female respondents predominated $(55 \%)$ and most farmers were more than 45 years old. Almost all pig farmers characterized their livelihood as a pig-keeping business (98\%), as opposed to communal village boar keeping (2\%). Up to $51 \%$ of household heads had received primary level education only (Table I).

\section{Pig demographic characteristics}

Demographic data are presented in Table II. Sizes of the pig herds were very small with an average of two adult pigs per farm. The pigs sampled in Lira and Moyo were predominantly local breed (58\%) females $(61.3 \%)$. However, a number of farmers had improved pig breeds (mainly crossbreeds).

\section{Pig management practices}

Tethering (Figure 2) was the most prevalent practice in both districts compared to free-ranging. Highly significant variations in the three management systems were observed between the rainy and the dry seasons $\left(\chi^{2}=6.2, p=0.00\right)$. The proportion of farmers who practiced free-ranging was higher in the dry season $(16 \%)$ than in the rainy
Table I

Pig farmers' demographic characteristics in two districts of Northern Uganda

\begin{tabular}{|c|c|c|c|}
\hline \multirow[t]{2}{*}{ Characteristic } & Lira District & Moyo District & \multirow[t]{2}{*}{ Total (\%) } \\
\hline & $\begin{array}{l}\text { Num. of } \\
\text { farmers }\end{array}$ & $\begin{array}{l}\text { Num. of } \\
\text { farmers }\end{array}$ & \\
\hline \multicolumn{4}{|l|}{ Sex } \\
\hline Male & 81 & 112 & $193(45.0)$ \\
\hline Female & 85 & 150 & $235(55.0)$ \\
\hline \multicolumn{4}{|l|}{ Age (years) } \\
\hline $15-24$ & 16 & 36 & $52(12.0)$ \\
\hline $25-34$ & 45 & 69 & $114(27.0)$ \\
\hline $35-44$ & 56 & 65 & $121(28.0)$ \\
\hline$\geq 45$ & 49 & 92 & $140(33.0)$ \\
\hline \multicolumn{4}{|l|}{ Nature of pig business } \\
\hline Producer & 164 & 256 & $420(98.0)$ \\
\hline Village boar keeper & 2 & 6 & $8(2.0)$ \\
\hline \multicolumn{4}{|l|}{ Level of education } \\
\hline Primary & 92 & 127 & $219(51.0)$ \\
\hline Secondary & 36 & 50 & $86(20.0)$ \\
\hline Tertiary & 38 & 85 & $123(29.0)$ \\
\hline \multicolumn{4}{|c|}{ Main source of income for the household } \\
\hline Pig keeping & 28 & 19 & 47 (11.0) \\
\hline Crop farming & 110 & 218 & $328(76.6)$ \\
\hline Other & 28 & 25 & $53(12.4)$ \\
\hline
\end{tabular}

Table II

Demographic characteristics of pigs sampled in two districts of Northern Uganda

\begin{tabular}{lccc} 
& Lira District & Moyo District & \\
\cline { 2 - 3 } Characteristic & Num. of pigs & Num. of pigs & Total (\%) \\
Sex & & & \\
Male & 130 & 150 & $280(38.7)$ \\
Female & 190 & 253 & $443(61.3)$ \\
Breed type & & & \\
Local & 194 & 223 & $416(58.0)$ \\
Cross & 96 & 180 & $276(38.0)$ \\
Exotic & 30 & 0 & $30(4.0)$ \\
Category & & & \\
Weaner & 52 & 3 & $55(7.6)$ \\
Gilt & 108 & 95 & $203(28.1)$ \\
Grower & 15 & 20 & $35(4.8)$ \\
Communal boar & 47 & 34 & $81(11.2)$ \\
Castrate & 30 & 109 & $139(19.2)$ \\
Sow & 68 & 142 & $210(29.1)$ \\
Age (months) & & & \\
4-6 & 179 & 39 & $218(30.2)$ \\
7-12 & 55 & 159 & $214(29.6)$ \\
$>12$ & 86 & 205 & $291(40.2)$
\end{tabular}

one (4\%). Likewise, the number of pigs tethered was lower in the dry season $(66 \%)$ than in the rainy one $(78 \%)$. 


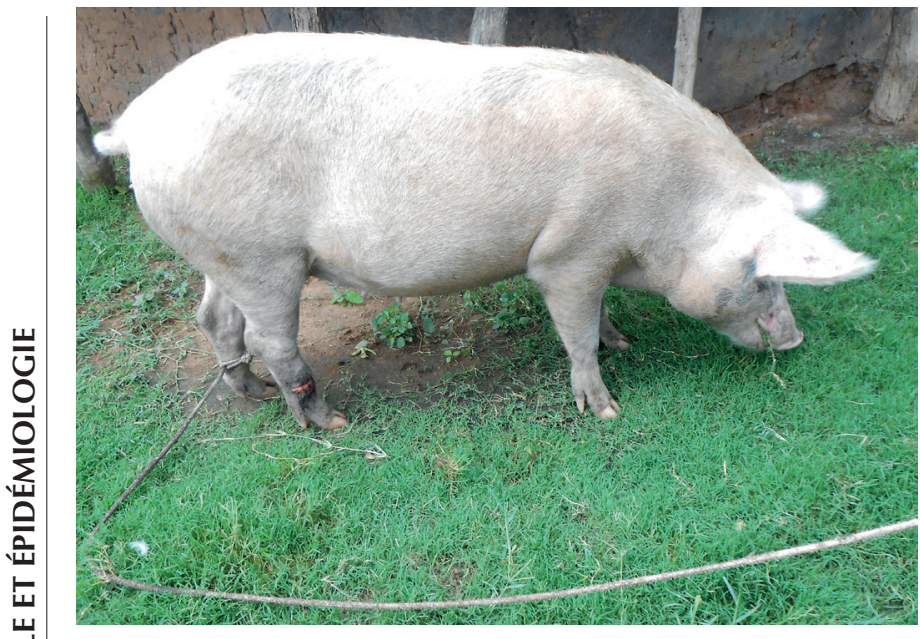

Figure 2: Tethered pig in a rural area of Northern Uganda.

\section{Pig feeding strategies}

There was significant variation in the feed types used in the rainy and dry seasons $\left(\chi^{2}=4.01, p=0.00\right)$. During the rainy season, pigs were mainly fed on crop residues (63\%) (raw or boiled cassava leaf and peelings, sweet potato vine, pumpkin and rice husk) and forages (25\%). In the dry season, they were mainly fed household kitchen swill (39\%) and crop residues (38\%). Commercial feeds including maize, rice bran, blood and fishmeal were used to supplement diets, but supplementation was less practiced during both the rainy and dry seasons.

\section{Pig health constraints}

Pig health challenges included ASF, and internal and external parasites (worms, lice and ticks). ASF was endemic in both districts and outbreaks occurred frequently especially during the dry season. ASF was perceived by farmers and key informants as the most important health constraint to pig systems. Besides ASF, which is known by local names, farmers could only mention clinical signs in their pigs, and the most commonly reported were diarrheas, respiratory problems, appetite and weight loss, shivering (fever sign), and skin affections. The high rate of piglet mortality and lack of feeds were also pointed out as major concerns. Farmers' knowledge of pig zoonoses was generally very poor. However, porcine cysticercosis was relatively known by farmers, traders and butchers, but its mode of transmission and impact to humans was not well understood. Pig slaughter was conducted in backyard slaughter slabs in both districts, and pork inspection did not frequently occur. In Moyo a community slaughter slab had been built in order to centralize pig slaughter, thus allowing easy meat inspection. Major constraints reported by veterinary officers, meat inspectors, extension workers and private animal health practitioners included i) failure by the community to report pig disease outbreaks to the district veterinary office, ii) uncontrolled movement of livestock and livestock products within and outside the districts, iii) high porosity of South Sudan and Moyo District border enabling easy exchange of livestock with limited sanitary control, iv) low awareness of the community about zoonotic diseases, and v) low level of farmers' knowledge regarding safe handling and processing of dead animals.

\section{Seroprevalence and risk factor analysis}

Out of 723 pig serum samples, only 75 were positive, implying that the overall prevalence was $10.4 \%$ (95\% confidence interval $[\mathrm{CI}]$ : 4.9-17.6). Moyo had more affected pigs (95\% CI: 13.2\%; 7.1-21.2) than Lira (95\% CI: 6.9\%; 2.9-13.9) (Table III). The herd seroprevalence was estimated at 13.7\% (95\% CI: 9.8-18.5) for Moyo, and 11.4\% (95\% CI: 7.0-17.2) in Lira (Table IV). Eleven potential risk factors were assessed for association with cysticercosis seroprevalence using a univariable logistic regression analysis (Table V). However, only the district was shown to be significantly associated with the condition (Table V). Results showed that the infection increased significantly with the age increase of pigs in Moyo $(\mathrm{p}=0.014 ; \mathrm{F}=6.09)$. There was no significant association observed between pig infection and age in Lira. Univariable analyses were run independently by district with no significant factors observed.

\section{DISCUSSION}

Pigs were kept in small numbers for subsistence mostly by women and children. The observed pig farming practices were characteristic of a typical smallholder pig farming system, which is predominant in

\section{Table III}

Pig seroprevalence of cysticercosis according to the location in two districts of Northern Uganda

\begin{tabular}{lcccc} 
District & Subcounty & $\begin{array}{c}\text { Num. of } \\
\text { pigs }\end{array}$ & $\begin{array}{c}\text { Num. } \\
\text { positive } \\
(\%)\end{array}$ & $\begin{array}{l}\% \text { Positive } \\
(\mathbf{C I})\end{array}$ \\
\hline \multirow{2}{*}{ Lira } & Ojwina (U) & 46 & 3 & $6.5(2.9-13.9)$ \\
& Barr (R) & 143 & 12 & $8.4(3.5-15.2)$ \\
& Lira (U) & 29 & 1 & $3.4(0.6-8.5)$ \\
& Adyel (U) & 42 & 2 & $4.8(1.6-11.3)$ \\
Moyo & Adekokwok (R) & 60 & 4 & $6.7(2.9-13.9)$ \\
& Total & 320 & 22 & $6.9(2.9-13.9)$ \\
Overall total & Moyo (R) & 188 & 21 & $11.2(5.6-18.8)$ \\
& Metu (R) & 215 & 32 & $14.9(8.7-23.50$ \\
& Total & 403 & 53 & $13.2(7.1-21.2)$ \\
& & 723 & 75 & $10.4(4.9-17.6)$
\end{tabular}

CI: $95 \%$ confidence interval; R: rural pig production; U: periurban pig production

\section{Table IV}

Herd seroprevalence of cysticercosis according to the location in two districts of Northern Uganda

\begin{tabular}{lcccc} 
District & Subcounty & $\begin{array}{c}\text { Num. } \\
\text { of } \\
\text { herds }\end{array}$ & $\begin{array}{c}\text { Num. } \\
\text { positive } \\
(\%)\end{array}$ & $\begin{array}{c}\% \text { Positive } \\
(\mathbf{C I})\end{array}$ \\
\hline \multirow{4}{*}{ Lira } & Ojwina (U) & 23 & 2 & $0.4(0.1-2.2)$ \\
& Barr (R) & 77 & 10 & $1.3(0.6-2.2)$ \\
& Lira (U) & 14 & 1 & $0.6(0.1-3.4)$ \\
& Adyel (U) & 20 & 2 & $0.7(0.1-3.2)$ \\
Moyo & Adekokwok (R) & 32 & 4 & $1.2(0.4-2.9)$ \\
& Total & 166 & 19 & $11.4(7.0-17.2)$ \\
& Moyo (R) & 96 & 11 & $11.4(5.9-19.6)$ \\
Overall total & Metu (R) & 166 & 25 & $15.0(9.9-21.4)$ \\
& Total & 262 & 36 & $13.7(9.8-18.5)$ \\
& & 428 & 55 & $12.8(9.8-16.4)$
\end{tabular}

CI: $95 \%$ confidence interval; R: rural pig production; U: periurban pig production 
Table V

Univariable regression of risk factors of cysticercosis in two districts of Northern Uganda

\begin{tabular}{|c|c|c|c|}
\hline Variable & Num. of pigs & $\begin{array}{c}\text { Num. } \\
\text { positives (\%) }\end{array}$ & $\mathbf{P}$ \\
\hline \multicolumn{4}{|l|}{ District } \\
\hline Lira & 320 & $22(6.9)$ & 0.01 \\
\hline Moyo & 403 & $53(13.2)$ & \\
\hline \multicolumn{4}{|l|}{ Pig sex } \\
\hline Male & 280 & $27(9.6)$ & 0.61 \\
\hline Female & 443 & $48(10.8)$ & \\
\hline \multicolumn{4}{|l|}{ Pig breed } \\
\hline Local & 416 & $42(10.1)$ & 0.83 \\
\hline Cross & 275 & $30(10.9)$ & \\
\hline Exotic & 30 & $3(10.0)$ & \\
\hline \multicolumn{4}{|l|}{ Pig category } \\
\hline Weaner & 55 & $4(7.3)$ & 0.24 \\
\hline Gilt & 203 & $17(8.4)$ & \\
\hline Grower & 35 & $5(14.3)$ & \\
\hline Entire boar & 81 & $5(6.2)$ & \\
\hline Castrate & 139 & $14(10.1)$ & \\
\hline Sow & 210 & $30(14.3)$ & \\
\hline \multicolumn{4}{|c|}{ Rainy season, day management } \\
\hline Free-ranging & 29 & $2(6.9)$ & 0.56 \\
\hline Tethering & 567 & $63(11.0)$ & \\
\hline Housed & 127 & $10(7.9)$ & \\
\hline \multicolumn{4}{|c|}{ Rainy season, night management } \\
\hline Free-ranging & 27 & $4(14.8)$ & 0.16 \\
\hline Tethering & 539 & $61(11.2)$ & \\
\hline Housed & 157 & $10(6.4)$ & \\
\hline \multicolumn{4}{|c|}{ Dry season, day management } \\
\hline Free-ranging & 114 & $14(12.3)$ & 0.62 \\
\hline Tethering & 477 & $50(10.5)$ & \\
\hline Housed & 130 & $11(8.5)$ & \\
\hline \multicolumn{4}{|c|}{ Dry season, night management } \\
\hline Free-ranging & 105 & $13(12.4)$ & 0.23 \\
\hline Tethering & 465 & $52(11.2)$ & \\
\hline Housed & 150 & $10(6.7)$ & \\
\hline \multicolumn{4}{|c|}{ Feed in rainy season } \\
\hline Crop residues & 454 & $47(10.4)$ & 0.17 \\
\hline Forage & 178 & $24(13.5)$ & \\
\hline Concentrate & 54 & $2(3.7)$ & \\
\hline Swill & 37 & $2(5.4)$ & \\
\hline \multicolumn{4}{|c|}{ Feed in dry season } \\
\hline Crop residues & 276 & $28(10.1)$ & 0.16 \\
\hline Forage & 87 & $8(9.2)$ & \\
\hline Concentrate & 79 & $3(3.8)$ & \\
\hline Swill & 281 & $36(12.8)$ & \\
\hline \multicolumn{4}{|c|}{ Dewormer used in pigs } \\
\hline Levamizole & 368 & $37(10.1)$ & 0.98 \\
\hline Ivermectin & 35 & $4(11.4)$ & \\
\hline Albendazole & 5 & $0(0.0)$ & \\
\hline
\end{tabular}

Uganda, where up to $80 \%$ of pig farmers hold a small stock ranging from one to five pigs (Ouma et al., 2015). In this study, the majority of the pig farmers interviewed were female. The proportion of femaleheaded households owning pigs in Uganda has increased significantly in the last 10 years, from $15 \%$ to $32 \%$. Regardless of who heads the household, it is widely agreed that women and children actively participate in managing pigs and other animals reared in homesteads (Uganda Bureau of Statistics, 2014).

The pig management practices reported in this study (free-ranging, tethering and housing) were similar to those reported in Central and Eastern Uganda, and in Gulu District in the North (Chenais et al., 2017; Dione et al., 2014). Although tethering was predominantly practiced in both districts, highly significant variations were noted in the three systems of management during the rainy and dry seasons. The number of free-ranging pigs was higher in the dry season than in the rainy one, a finding which concurs with previous studies in Uganda and the Democratic Republic of Congo (Dione et al., 2014; Lekule and Kyvsgaard, 2003). These changes in management systems with seasonal patterns have mainly been associated with limited feed resources and minimal crops during the dry season (Lekule and Kyvsgaard, 2003). Most farmers favored tethering as an alternative to roaming, as they could not afford building proper housing for pigs. In comparison with the housing system, it is considered to be less labor intensive (Dione et al., 2014).

A significant variation in feed types given to the pigs was noted in this study, whereby crop residues and forages were mainly used in the rainy season, whereas swill and crop residues predominated during the dry season. During the rainy season, there was an increased availability of forage and crop residues such as cassava leaf and sweet potato vine. During the dry season, feeds became scarce, resulting in farmers tethering their pigs in grazing fields with scanty pastures and supplementing them with swill (Braae et al., 2015). Limited use of commercial feed (concentrate) was reported probably because of their high cost (Lekule and Kyvsgaard, 2003).

The rearing systems reported here faced many challenges such as exposure of pigs to diseases, theft and predation, environmental stressors, poor nutrition, as reported elsewhere (Lekule and Kyvsgaard, 2003). Pig farmers also faced other challenges such as a high disease prevalence (especially ASF), feed scarcity and limited access to markets, which are the same challenges reported in other districts of Uganda (Dione et al., 2014; Muhanguzi et al., 2012).

The overall cysticercosis prevalence (10.4\%) was within the range of that reported elsewhere in the country (Kungu et al., 2016; Nsadha et al., 2014; Waiswa et al., 2009). The higher odds of disease occurrence in Moyo could be attributed to a greater exposure of pigs to the infection given that Moyo had a more extensive pig system than Lira. Tethering and free-ranging represented risks that could not be underestimated.

Traditional rearing systems increase the likelihood of pigs accessing human fecal matter contaminated with tapeworm eggs, facilitating the completion and maintenance of the transmission cycle of pork tapeworms and cysticercosis (Carabin et al., 2015; Mwanjali et al., 2013; Thys, 2016; Braae et al., 2015). In Uganda, the occurrence of cysticercosis is a major public health concern given that farmers who are also consumers have little awareness of the condition and how to prevent and control it (Kungu et al., 2017b). Therefore, there is a need to raise awareness among pig value chain actors and stakeholders about the risks of infection with Taenia spp. through community advocacy campaigns with relevant authorities. Improved prevention and mitigation measures are highly needed to minimize transmission of the disease to people, with apparent benefits to the pig sector in terms of incomes and human health. Further studies should focus on the assessment of the roles of pig value chain actors in the management of cysticercosis and to investigate the effectiveness of approaches that promote the participation of farmers and other actors and stakeholders in the control of the disease. 


\section{CONCLUSION}

The study reported that traditional tethering was the most popular system of pig production in the two districts, showing the challenge that impedes improving the productivity of the pig industry. The pig management systems posed the silent risk of maintaining pig-related diseases. The observed cysticercosis prevalence confirmed the endemic occurrence of the disease in the districts. Since the serological test used was not $T$. solium specific, surveys using specific tests such as whole carcass inspection and PCR should be carried out to estimate T. solium cysticercosis burden. In-depth studies should also be performed to understand the factors that led to the significant difference of cysticercosis seroprevalence between Moyo and Lira districts. This study and other similar works could form a preliminary basis for the development and implementation of feasible control strategies countrywide.

\section{Acknowledgments}

This study was funded by USAID linkage Fund to CGIAR Research Program on Livestock. We thank the district veterinary officers of Lira (Dr. W. Okwir) and Moyo (Dr. R. Akule), as well as district veterinary extension staffs and pig farmers for their cooperation, and technical and logistical support.

\section{Author contributions statement}

MD conceptualized the study; MD and MA designed and coordinated the study; MA, JA, WCA and JMK collected the samples and household information; CM and JA performed the laboratory analysis; JMK performed the statistical analysis; JMK and MD wrote the manuscript.

\section{REFERENCES}

Adenuga A., Mateus A., Ty, C., Borin K., Holl D., San S., Duggan V., et al., 2018. Seroprevalence and awareness of porcine cysticercosis across different pig production systems in south-central Cambodia. Parasit. Epidemiol. Cont., 3 (1): 1-12, doi: 10.1016/j.parepi.2017.10.003

Braae U.C., Harrison W., Lekule F., Magnussen P., Johansen M.V., 2015. Feedstuff and poor latrines may put pigs at risk of cysticercosis. A case-control study. Vet. Parasitol., 214 (1-2): 48-55, doi: 10.1016/j.vetpar.2015.08.009

Carabin H., Millogo A., Cissé A., Gabriël S., Sahlu I., Dorny P., Bauer C., et al., 2015. Prevalence of and factors associated with human cysticercosis in 60 villages in three provinces of Burkina Faso. PLoS Neglect. Trop. Dis., 9 (11): 1-20, doi: 10.1371/journal.pntd.0004248

Carabin H., Millogo A., Praet N., Hounton S., Tarnagda Z., Ganaba R., Dorny P., et al., 2009. Seroprevalence to the antigens of Taenia solium cysticercosis among residents of three villages in Burkina Faso: A cross-sectional study. PLoS Neglect. Trop. Dis., 3 (11), 7, doi: 10.1371/journal.pntd.0000555

Chenais E., Boqvist S., Sternberg-Lewerin S., Emanuelson U., Ouma E., Dione M., Aliro T., et al., 2017. Knowledge, attitudes and practices related to African swine fever within smallholder pig production in Northern Uganda. Transbound. Emerg. Dis., 64 (1): 101-115. doi: 10.1111/tbed.12347.

Dione M.M., Akol J., Roesel K., Kungu J., Ouma E.A., Wieland B., Pezo D., 2017. Risk factors for African swine fever in smallholder pig production systems in Uganda. Transbound. Emerg. Dis., 64 (3): 872-882, doi: 10.1111/tbed.12452

Dione M.M., Ouma E.A., Roesel K., Kungu J., Lule P., Pezo D., 2014. Participatory assessment of animal health and husbandry practices in smallholder pig production systems in three high poverty districts in Uganda. Prev. Vet. Med., 117 (3-4): 565-576, doi: 10.1016/j.prevetmed.2014.10.012

FAOSTAT, 2014. Food balance sheet. FAO, Rome, Italy

Krecek R.C., Mohammed H., Michael L.M., Schantz P.M., Ntanjana L., Morey L., Werre S.R., et al., 2012. Risk factors of porcine cysticercosis in the Eastern Cape Province, South Africa. PloS One, 7 (5), e37718, doi: 10.1371/journal. pone.0037718
Kungu J.M., Dione M.M., Ejobi F., Harrison L.J.S., Poole E.J., Pezo D., Grace D., 2017. Seroprevalence of Taenia species in rural and urban smallholder pig production settings in Uganda. Acta Tropica, 165: 110-115, doi: 10.1016/j.actatropica.2016.01.016

Kungu J.M., Dione M.M., Ejobi F., Ocaido M., Grace D., 2017. Risk factors, perceptions and practices associated with Taenia solium cysticercosis and its control in the smallholder pig production systems in Uganda: a cross-sectional survey. BMC Infect. Dis., 17 (1): 1, doi: 10.1186/s12879016-2122-x

Lekule F.P., Kyvsgaard N.C., 2003. Improving pig husbandry in tropical resource-poor communities and its potential to reduce risk of porcine cysticercosis. Acta Trop., 87 (1): 111-117, doi: 10.1016/S0001706X(03)00026-3

Muhanguzi D., Lutwama V., Mwiine F.N., 2012. Factors that influence pig production in Central Uganda. Case study of Nangabo Sub-County, Wakiso District. Vet. World, 5 (6): 346-351, doi: 10.5455/vetworld.2012.346-351

Mwanjali G., Kihamia C., Kakoko D.V.C., Lekule F., Ngowi H., Johansen M.V., Thamsborg S.M., et al., 2013. Prevalence and risk factors associated with human Taenia solium infections in Mbozi District, Mbeya Region, Tanzania. PLoS Neglect. Trop. Dis., 7 (3), e2102, doi:10.1371/journal. pntd.0002102

Mwape K.E., Blocher J., Wiefek J., Schmidt K., Dorny P., Praet N., Chiluba C., et al., 2015. Prevalence of neurocysticercosis in people with epilepsy in the Eastern province of Zambia. PLoS Neglect. Trop. Dis., 9 (8): 1-15, doi: 10.1371/journal.pntd.0003972

Nsadha Z., Thomas L.F., Fèvre E.M., Nasinyama G., Ojok L., 2014. Prevalence of porcine cysticercosis in the Lake Kyoga Basin, Uganda. BMC Vet. Res., 10: 239, doi: 10.1186/s12917-014-0239-y

Ouma E., Dione M., Lule P., Pezo D., Marshall K., Roesel K., Mayega L., et al., 2015. Smallholder pig value chain assessment in Uganda: results from producer focus group discussions and key informant interviews (res. rep.). ILRI, Nairobi, Kenya

Ouma E., Dione M., Lule P., Roesel K., Pezo D., 2014. Characterization of smallholder pig production systems in Uganda: Constraints and opportunities for engaging with market systems. Livest. Res. Rural Dev., 26 (3)

Praet N., Speybroeck N., Manzanedo R., Berkvens D., Nsame Nforninwe D., Zoli A., Quet F., et al., 2009. The disease burden of Taenia solium cysticercosis in Cameroon. PLoS Neglect. Trop. Dis., 3 (3), 8, doi: 10.1371/ journal.pntd.0000406

Rodriguez-Hidalgo R., Benitez-Ortiz W., Praet N., Saa L.R., Vercruysse J., Brandt J., Dorny P., 2006. Taeniasis-cysticercosis in Southern Ecuador: assessment of infection status using multiple laboratory diagnostic tools. Memorias Instit. Oswaldo Cruz, 101 (7): 779-782, doi: 10.1590/S007402762006000700012

Sciutto E., Martínez J.J., Huerta M., Avila R., Fragoso G., Villalobos N., de Aluja A., et al., 2003. Familial clustering of Taenia solium cysticercosis in the rural pigs of Mexico: hints of genetic determinants in innate and acquired resistance to infection. Vet. Parasitol., 116 (3): 223-229, doi: 10.1016/j.vetpar.2003.07.003

Sreedevi C., Hafeez M., Kumar P.A., Rayulu V.C., Subramanyam K.V., Sudhakar K., 2012. PCR test for detecting Taenia solium cysticercosis in pig carcasses. Trop. Anim. Health Prod., 44 (1): 95-99, doi: 10.1007/s11250011-9893-2

Thrusfield M., 2007. Veterinary Epidemiology, 3rd edn. Blackwell Science, Oxford, UK

Thys S., Mwape K.E., Lefèvre P., Dorny P., Phiri A.M., Marcotty T., Phiri I.K., et al., 2016. Why pigs are free-roaming: Communities' perceptions, knowledge and practices regarding pig management and taeniasis/cysticercosis in a Taenia solium endemic rural area in Eastern Zambiat. Vet. Parasitol., 225, 33-42, doi: 10.1016/j.vetpar.2016.05.029.

UBOS, MAAIF, 2009. National livestock census. Ministry of Agriculture, Animal Industry and Fisheries, Entebbe / Uganda Bureau of Statistics. Kampala, Uganda

Uganda Bureau of Statistics, 2014. Statistical abstract. Statistics House, Kampala, Uganda, $305 \mathrm{p}$.

Waiswa C., Fèvre E.M., Nsadha Z., Sikasunge C.S., Willingham A.L., 2009. Porcine cysticercosis in Southeast Uganda: seroprevalence in Kamuli and Kaliro districts. J. Parasitol. Res., 2009: 375493, doi: 10.1155/2009/375493 


\section{Résumé}

Kungu J.M., Masembe C., Apamaku M., Akol J., Amia W.C., Dione M. Systèmes d'élevage porcin et cysticercose au nord de l'Ouganda

Les systèmes rudimentaires d'élevage de porcs, non orientés vers le marché, ont été impliqués dans la persistance de la cysticercose à Taenia spp., maladie endémique présentant un grave problème de santé publique en Ouganda. Nous avons étudié la séroprévalence et les principaux facteurs prédisposant de la maladie à Moyo et à Lira, deux districts producteurs de porcs au nord du pays. Des enquêtes sérologiques transversales ont été menées dans 428 élevages porcins (Moyo, 262 ; Lira, 166). Deux porcs adultes étaient gardés en moyenne par troupeau. En milieu rural ils étaient souvent attachés, la divagation étant occasionnelle. Le confinement en enclos était observé en milieu périurbain. Les animaux étaient principalement alimentés avec des résidus de culture et des fourrages pendant la saison des pluies, et des restes d'aliment des ménages et les résidus de culture en saison sèche. La majorité des éleveurs de l'enquête étaient des femmes (55 \%) âgées de plus de 45 ans ; $51 \%$ des éleveurs avaient le niveau de I'école primaire. Au total 723 échantillons sériques porcins ont été prélevés (Moyo, 403 ; Lira, 320). Ils ont été analysés pour la détection des antigènes de Taenia spp. en utilisant le test B158C11A10/B60H8A4 Elisa-antigène. La séroprévalence animale totale de l'antigène sérique de Taenia spp. était de 10,4\% (intervalle de confiance [IC] à $95 \%: 4,9-17,6$ ). Elle a été la plus élevée à Moyo avec 13,2\% (IC à $95 \%$ : 7,1-21,2) vs 6,9\% (IC à $95 \%: 2,9-13,9$ ) à Lira. La séroprévalence au niveau du troupeau a été estimée à 13,7\% (Cl $95 \%$ : 9,818,5) à Moyo vs 11,4\% (Cl $95 \%: 7,0-17,2)$ à Lira. Parmi les 12 variables explicatives évaluées pour I'association avec la séroprévalence observée, seul le district d'origine était significatif ( $p=0,01)$. Les porcs originaires de Lira étaient un facteur protecteur contre la cysticercose à Taenia spp. (odds ratio : $0,54)$. Ces résultats ont souligné le besoin urgent de mettre en place des mesures de lutte pour minimiser le risque de transmission aux consommateurs de porc dans ces districts.

Mots-clés : porcin, conduite d'élevage, Taenia spp., cysticercose, séroprévalence, facteur de risque, Ouganda

\section{Resumen}

Kungu J.M., Masembe C., Apamaku M., Akol J., Amia W.C., Dione M. Sistemas de crianza porcina y cisticercosis en el norte de Uganda

Los sistemas más rudimentarios de cría de cerdos, no orientados al mercado, se han visto implicados en la persistencia de la cisticercosis de Taenia spp., enfermedad endémica que representa un grave problema de salud pública en Uganda. La seroprevalencia y los principales factores predisponentes de dicha enfermedad fueron estudiados en Moyo y Lira, dos distritos productores de carne de cerdo en el norte del país. Para ello se realizaron encuestas serológicas transversales en 428 granjas porcinas (Moyo, 262; Lira, 166). Se contabilizó una media de dos cerdos adultos por rebaño. En las zonas rurales, los animales se encontraban principalmente atados, con desplazamientos libres ocasionales. En las zonas periurbanas sin embargo se observó un predominio del sistema de estabulación. También se observó que la alimentación se basa principalmente en los residuos de cultivos y los forrajes durante la época lluviosa, mientras que en la época seca se distribuyen residuos de cocina (domésticos) y otros residuos de cultivo. En la encuesta, la mayoría de los productores fueron mujeres (55\%) mayores de 45 años y el $51 \%$ contaban con el nivel de escolaridad primario. Se recogieron en total 723 muestras de suero porcino (Moyo, 403; Lira, 320). Para la detección de antígenos de Taenia spp., las mismas fueron analizadas utilizando el test Elisa B158C11A10/B60H8A4. La seroprevalencia animal total de antígeno sérico de Taenia spp. resultó ser del 10,4\% (intervalo de confianza [IC] del 95\%: 4,9-17,6). Los valores más altos se encontraron en Moyo (13,2\%; IC 95\%: 7,1-21,2) vs 6,9\% (IC 95\%: 2,9-13,9) en Lira. La seroprevalencia a nivel del rebaño se estimó a la altura del $13,7 \%$ (IC 95\%: 9,8-18,5) en Moyo y al 11,4\% (IC 95\%: 7,0-17,2) en Lira. Entre las 12 variables predictivas evaluadas para la asociación con la seroprevalencia observada, solo el distrito de origen resultó ser significativo $(p=0,01)$. Los cerdos procedentes de Lira fueron un factor protector contra la cisticercosis provocada por Taenia spp. (odds ratio: 0,54). Estos resultados indican la necesidad urgente de establecer medidas de control para minimizar el riesgo de transmisión a los consumidores de carne de cerdo en estos distritos.

Ganado bovino: cerdo, manejo del ganado, Taenia spp., cisticercosis, seroprevalencia, factores de riesgo, Uganda 
